ARTICLE

DOI: $10.1057 /$ s41599-018-0132-6

\title{
Right-wing populism and the dynamics of style: a discourse-analytic perspective on mediated political performances
}

\author{
Mats Ekström¹, Marianna Patrona ${ }^{1} \&$ Joanna Thornborrow ${ }^{1}$
}

\begin{abstract}
This article offers new ways of conceptualising style in right wing populist communicative performances, by foregrounding a structured and conceptually informed use of "style" that moves beyond the descriptive sense routinely employed in political communication. Specifically, it explores how a discourse-analytic approach to mediated populist discourse can inform and advance the current understanding of populist 'style' by analysing some contextually produced linguistic and discursive choices in populist rhetorical repertoires -i.e., the communicative strategies that are deployed in mediated contexts for right-wing populist political communication. Taking three illustrative examples of right wing populist party performances on TV news and current affairs broadcasts in Greece (GD), France (FN) and the UK (UKIP), the speakers' use of a range of rhetorical devices is examined using models from socio-linguistics and discourse analysis: aspects of register shifts by GD in blame attribution speeches, interactional 'bad manners' in a French political debate, and Nigel Farage speaking 'candidly' in three different contexts of news reporting from the UK. In taking such a qualitative approach, it is argued that populist style cannot be defined in terms of one single feature, or set of features, common to all right wing populists and transferrable from one socio-cultural context to another, but more usefully as a set of motivated choices among alternative semiotic resources (linguistic/discursive, interactional and visual), which have social and cultural resonance. This focus on micro-level features of mediated interaction thus offers a more fine-grained understanding of style than is currently the case, as it shows how right-wing populist politicians' performative styles are situated within specific (here European) socio-cultural and political communicative contexts; in this study, this is to say, the various television broadcasts in which they occur.
\end{abstract}

\footnotetext{
${ }^{1}$ Université de Bretagne Occidentale (University of Western Brittany), Brest, France. Correspondence and requests for materials should be addressed to J.T. (email: joanna.thornborrow@univ-brest.fr)
} 


\section{Introduction: populist style as discursive performance}

tyle and performance are two concepts that have been moving steadily centre stage in the media's reporting of, and commentary on, political events recently, particularly since right wing populist parties and politicians have been gaining ground and winning votes in local and national elections across Europe and further afield. The concept of political style of course is not a recent one. Dating back to Aristotle, rhetorical skill, convincing 'performances' and the successful transmission of a political message to win votes are as old as politics itself. The consideration of style and performance as phenomena that can be analysed through the lens of sociolinguistics and discourse analysis as a key to understanding identity construction, is however more recent, and in this paper we examine some aspects of contemporary right wing populist style using theory and methods developed within this field.

As the success of populist politics across western democracies seems to be taking an increasingly firm hold (the populist radicalright Alternative for Germany (AfD) party entering the German parliament, as the third biggest party in votes, being the latest example as we write), the relationship between the media and the styling of a political message is now fully in the spotlight. Politicians are frequently reported by the media as having distinctive ways of speaking and behaving which, in some way, function to create a link between them as individuals and their policies, and which are also seen to enhance (or diminish) their electoral chances of success. However, how exactly these ways of speaking and behaving relate to populism, and particularly to right wing populism, is a complex issue and not so easily defined. Two brief examples below illustrate this point from recent election campaigns in France and the UK.

In the week before the second round of voting in the French presidential elections 2017, the two final candidates were interviewed separately by David Pujadas on France 2. When asked why he had chosen the same media video footage as his opponent Marine Le Pen to symbolise his campaign for that interview (the opening footage showed in each case their respective visits to a factory in northern France threatened by closure), Emmanuel Macron said that this event "was important from a political point of view because it showed the difference in our styles and the two different ways that we relate to French people and in particular to workers." He went on to say that he was telling them the truth whereas she was telling them what they wanted to hear, that he had spent time with them while she had just 'dropped in' for a photo opportunity to hug a few workers ${ }^{1}$. Also, shortly after the Grenfell Tower disaster in London, in an interview with BBC's James Coomarasamy Huff Post reporter Paul Waugh commented on the behaviour of Theresa May and Jeremy Corbyn when visiting the site, saying that: "she hadn't come to listen; to ask people's own personal experience on the ground and that stood obviously in sharp contrast to Jeremy Corbyn who arrived and actually was in listening mode and was seen hugging people", to which Coomarasamy replied that this once again exposed differences in style between them ${ }^{2}$. Corbyn and Le Pen can hardly be said to occupy the same political ground, and the kind of empathy required in the two cases is not comparable, but politicians' expressions of solidarity with victims of criminal negligence or of global economics tend to be judged in terms of levels of sincerity. Corbyn's actions were perceived as authentic in relation to May's perceived remoteness from the people, while Macron's aim, as previous media reporting of the event had also done, was to cast doubt on the sincerity of Le Pen's motives for this lightning trip up to Amiens.

There is a tradition of analysing style in linguistics and discourse analysis that can be brought to bear on the sorts of informal comparisons of 'style' we see offered above between May, Corbyn, Macron and others, and understanding this tradition requires a formal definition. Style is always part of a communicative context and is put to work and made meaningful within that context. Both Charadeau (2013) and Herkman (2016) have argued that in order to fully understand how populist reason is constructed and becomes meaningful, we need to analyse not just its socio-historical context, but also the situated communicative context within which it is discursively produced. Pierre Bourdieu also describes style as systems of social distinctiveness, as "a set of systematic differences, apprehended syncretically" (1991, p. 38), and our aim is to show how the success of populist performances is dependent on the shift of focus to these distinctions, which are often discursive, and contextually situated, rather than on conventional political ideological differences. It is through such differences, and in breaking the norms and conventions of public communication, that the 'non-establishment' is being performed.

Claiming the centrality of style is however not to suggest that populism is nothing but style. Populism is a truly contested concept. Various definitions have been proposed indicating different theoretical accounts, as well as the multidimensional characteristics of populism (Ekström and Morton, 2017, Moffitt, 2016, Mudde, 2007, Muller, 2016). This is not the place for indepth discussion of the different conceptualisations of populism. However, for the sake of clarity, we perceive populism as both a political discourse, or 'thin-centred ideology', representing politics and society as structured by a fundamental antagonistic relationship between 'the elite' and 'the people' (Canovan, 1999, Mudde, 2007, De Cleen and Stavrakakis, 2017), and the performance of anti-establishment stances and identities, and claims to being one of 'the people', in which the dynamic processes of styling are absolutely central. Populism is present both on the left and the right of the political spectrum, however in this study we focus on the performative styles of right-wing populist politicians. In this context, populist styles are typically invoked to serve forms of nationalism, such as when the appeal to 'the people' is an appeal to 'the native people' and the styles connect to national myths and stereotypical identities.

In their introduction to a recent volume on style, mediation and sociolinguistic change, Mortensen et al. point out that style "always presupposes mediation, but technological media have unique styling resources to shape how meanings are made and interpreted through linguistic and semiotic performance" (2017, p. 1). This notion of 'styling resources' operating within a mediated context offers a framework for exploring aspects of style that need to be incorporated into analyses of the performance of political populism. At least four aspects seem to us to be crucial here:

1. Style refers to signifying and semiosis. Styles are adopted and performed in the use of discursive, interactional and visual semiotic resources and anchored in (socio-cultural) sign systems.

2. Style refers to contextualised repertoires of speaking and behaving through which identities and socio-cultural affiliations are claimed and communicated. In populism, embodied styles may be invoked to signify closeness to the people and represent socio-cultural identities.

3. Style is relational and dynamic. The meaning and values of particular styles are dependent on context and in contrast to other conventional styles (e.g., the populist style in contrast to technocratic style; unpolished or blunt talk in contrast to polished talk).

4. The power of style is related to the way in which value hierarchies and/or moral assessments are invoked; how a particular style can be claimed to have more social 'capital' in a particular context (for example being more authentic and representing the 'real people' as opposed to the elite, alienated style of the political establishment). 
In view of these points, we believe it is more useful to approach the mediated performance of political populism as an ongoing dynamic process of styling, rather than a static production where a set of linguistic and discursive choices always signify identity and value in similar ways. In so doing, we offer a new approach to analysing current right wing populist style in contemporary media contexts for listening and viewing publics, and a deeper understanding of what style is, and why it has become so central to current definitions of populism (Bossetta, 2017, Corner and Pels, 2003, Krämer, 2014, Moffitt 2016, Mudde, 2007, Schoor, 2017, Street, 2003).

The mention of differences of style in political performance referred to in the two examples earlier can thus be examined from a more theoretical angle in terms of what politicians are perceived to 'do differently' from one another. Sociolinguistics and discourse analysis can offer alternative perspectives on how features of 'form' rather than just 'content' are mobilised by political actors as indexes of social values in mediated political performances that contribute to persuasive constructions of social identity which have little to do with truth values or factual veracity. Research on mediated talk in the public sphere has shown that 'being authentic' and 'being sincere' are interactional, discursive accomplishments, produced in specific contexts for particular audiences. For example, Montgomery, 1999 analysed differences in the linguistic characteristics of speeches by public figures (Tony Blair, the Queen and Earl Spencer) in their address to the public after the death of Princess Diana in 1997, and how these differences contributed to the public's assessment of the speakers as more, or less, sincere. Myers, 2000 discusses aspects of sincerity in vox pop interviews with members of the public in relation to that same event. Authenticity has also been considered from various theoretical perspectives in empirical discourse analyses of talk produced in a wide range of broadcast contexts, from radio phone-in calls to celebrity interviews and reality TV shows (Thornborrow and Van Leeuwen, 2001, Tolson, 2006). Montgomery has recently argued that the improbable electoral success in 2016 of Donald Trump owed much to his discursive style:

Its appeal to a significant segment of the population goes way beyond its content. Trump has managed to fashion a manner of speaking that ventriloquises a directness of speech-replete with pithy resonances and sometimes humorous overstatements-which catches the vernacular rhythms of those who have little left to lose. (Montgomery, 2017, p. 19)

Appearing to be close to 'ordinary' people and taking up their concerns against a powerful, privileged and distant elite is another of the characteristics of populist style that has been identified in much political communication research (Ekström and Morton, 2017). Ever since the pioneering work of Sacks, 1984, 'being ordinary' has also been considered as an interactional accomplishment, and research on broadcast talk has explored the notion of 'ordinariness' as a discursively occasioned phenomenon, rather than as an intrinsic quality that can be unproblematically ascribed to social actors in a mediated event (Thornborrow, 2015, Tolson, 2006).

Generally, increased rhetorical appeal to 'pathos' (emotional appeal) as opposed to substantive facts is seen as a characteristic of populist political communication today, and moreover, it has been recognised that mainstream politicians may adopt a populist political style, while maintaining a non-populist agenda (Bossetta, 2017). A general argument in this literature is that features of 'populist' communicative style include heightened emotionality, dramatisation, and the use of colloquial language on the part of populist actors to appeal to the people, to perform anti-establishment stances, and to increase newsworthiness in the context of a media logic that is based on similar stylistic preferences (i.e., for the emotional and the dramatic) often referred to as 'media populism' (Krämer, 2014).
Rather more elaborated analyses of political style can be found in Pels (2003), who refers to a "style-revolution" in (mediated) politics in general, and discusses style as an aspect of performed personalities and identities: "Style refers to a heterogeneous ensemble of ways of speaking, acting, looking, displaying, and handling things, which merge into a symbolic whole that immediately fuses matter and manner, message and package, argument and ritual." (2003, p. 45). Similarly, Bossetta, 2017 points out the mainstream adoption of populist political style in the 2014 Europe televised debates in the UK, viewing populist style as one that privileges conflict and crises, as opposed to consensus and substantive facts. Moffitt, 2016 too views populism as an essentially (although not exclusively) political style, defining it as "the repertoires of embodied, symbolically mediated performances made to an audience that are used to create and navigate the fields of power that comprise the political, stretching from the domain of government through to everyday life" (2016, p. 38). For Moffitt, "bad manners" (being unpolished and incorrect) characterises a typical populist style, but so also does "the appeal to the people" and the "performance of crises". These features, he argues, distinguish "populist political style" from "technocratic political style", but what actually constitutes style, and how it relates to the broader concept of performance, still remains somewhat unclear (cf. Schoor, 2017, p. 657, for the need to "disentangle" the hitherto underdeveloped concept of political style).

How can a discourse analytical approach illuminate concepts such as the 'appeal to the people', 'bad manners' and the 'performance of crisis' as manifested in populist discourse and described by Moffitt and others above? Firstly, by providing a context sensitive, analytical procedure for examining how populist discourse draws on linguistic tropes and discursive practices as resources within specific socio-cultural contexts, here the mediated context of broadcast news. For instance, what constitutes 'performance of crisis' in right wing populist discourse and is it always the same performance? How do right wing populist politicians behave badly and are 'bad manners' in one context interpreted as such, with the same communicative effect, in another? Secondly, a qualitative approach to the situated details of populist performances (particularly on television where visual and other framing resources are also brought into play) can offer crucial insights into how populist politicians mobilise stylistic resources to discursively produce and display their difference from mainstream 'technocratic' political discourses. Fairclough, 2016, Van Leeuwen, 2008 and others show how inter-discursivity (the borrowing of language styles and registers from one genre in another) and re-contextualisation (the embedding of selected discursive practices from one context or medium into a new one) can produce new meanings either as critique or legitimation of those practices (Thornborrow, 2015). Thus we can explore how stylistic choices, for example, the mixing of high and low language forms in the discourse of Golden Dawn, the disruption of conventional mediated political interactions by the Front National, or the discourse of anti-expertise in Nigel Farage's direct talk, become meaningful in that specific mediated context. Finally perhaps most importantly, as Higgins, 2013 points out, populist discourse is an inherently tactical endeavour, and in order to maintain its persuasive purchase it has to remain anti-political in contexts where much mainstream political discourse is adopting forms of previously successful populist rhetoric. Populist 'style' therefore can not be other than flexible and dynamic in terms of its relationship to other evolving political discourses, so identifying it as a set of core features, in the sense of pinning down a definitive populist 'style' becomes inevitably problematic.

The styling of mediated political performances can also be found in the selection of forms of contextually embodied behaviours, with what Goffman (1959) would refer to as having 'given' communicative values, such as those found in visual images of TV 
news reporting. For example, in recent campaigns in France and the UK, Nigel Farage was often shown drinking and smoking near a pub, while Marine Le Pen's cultivation of a more presidential image in 2017 was indexed by a visual focus on her new haircut and the length of her high-heeled shoes. But it can also be found in politicians' motivated choice of discursive behaviours in contexts where their relational, interpersonal and interactional performances become the focus of media attention and commentary.

It is noticeable that, despite extensive existing research in the domain of language and politics ${ }^{3}$, there is a lack of interdisciplinary cross-reference between the notion of style in political communication research, and the available literature on style in sociolinguistics and discourse studies. In this work, the study of contextual and performative aspects of style is considered central to understanding indexes of social and cultural identities and values. In variationist sociolinguistics, language style (i.e., in terms of phonological, lexical and grammatical variation) has been analysed as a significant marker of more or less formal contexts for speech, as well as of social and cultural memberships and identities (for an overview, see Coupland, 2007). For example, Bell developed the concept of 'audience design' in his analysis of style shifting in the context of news broadcasting, where he found that the same news presenters changed their speech style according to whether they were working for the local or the national radio station (Bell, 1991). In his analysis of a recording of labour politician Nye (Aneurin) Bevan's speech at a public rally in $1956^{4}$, Coupland shows how Bevan was able to draw on linguistic resources of phonological variation to produce two contrasting 'voices', that of a powerful Westminster elite which is mocked by that of a critical, sceptical vernacular:

Bevan's debating successes hinged on establishing ludicrous or foolish or inconsistent personas for his Tory opponents, and in building identities and stances for himself in relation to them and working people that listeners could 'take away with them' and possibly adopt as their own. (Coupland, 2007, p. 163)

Critical discourse analysts have also examined linguistic style as a contextual feature that indexes social identity and social, hierarchical value systems. Fairclough suggests that style can be defined as "identities, or 'ways of being', in their semiotic aspects" (2006, p. 89). Kress too emphasises that style "is the effect of a series of choices" (2010, p. 28) in the design of actions and repertoires, and that these choices, adopted and embodied by individuals, produce a style that becomes meaningful in contrast to others. Fairclough (2000) accounts for the success of former labour prime minister Tony Blair as being related directly to his performance of a particular social identity:

A crucial part of the success [of Blair's style] is his capacity to, as it were, 'anchor' the public politician in the 'normal person ' $[. .$.$] the sort of 'normal person' that comes across is$ very much 'middle-class' and 'middle-England' in values, outlook and style. (Fairclough 2000, p. 7-8).

Our intention here is not to compare Bevan and Blair with right wing populist politicians, but to point out that sociolinguists and discourse analysts showed how both these political figures drew on linguistic and discursive resources to construct social identities that appealed to particular constituencies of voters, just as today's right wing populist politicians style their identities to appeal to those whose support they seek. In news coverage of recent elections, vox pop interviews with UKIP supporters frequently contained positive references to Nigel Farage's perceived blunt way of speaking, brushing aside 'political correctness' and 'saying out loud what everyone really thinks'. In France during the 2017 election campaign, Marine Le Pen's supporters interviewed on news broadcasts could be heard saying similar things. Laying claim to a suppressed yet shared majority public opinion has been a powerful device in voicing policies that are anti-political establishment elites, anti-European and anti-immigration. How has the expression of such views been legitimised in the mediation of contemporary right wing populism? We believe that an analysis of style-understood as the mobilisation of particular communicative resources-may be part of the answer to that question.

In the following sections, we develop these arguments through a set of empirical examples taken from our corpus of French, Greek and UK television news and current affairs data ${ }^{6}$ and, in the final section, we discuss the contributions of this approach to a more fine-grained understanding of what constitutes populist style in relation to mediated performances and identity construction in a given socio-cultural political context.

\section{Populist performances: Golden Dawn, Florian Philippot and Nigel Farage}

In the following examples from Greece, France and the UK, we will argue that right wing populist discourse continually distinguishes itself from, and is disruptive of, conventional established styles of mediated politics, i.e., ways of doing public discourse and ways of being in political contexts, so as to consistently reproduce antagonistic relationships between mainstream political discourses of the establishment and a fictive, homogenised public, 'the people'. In the data extracts discussed, we show how linguistic registers, interactional behaviours and discursive strategies produced in specific cultural (broadcast) contexts enable populist politicians to appeal to 'the people' by claiming the moral high ground, subverting and undermining the establishment, and producing identity performances that signify closeness to 'the people', as opposed to the perceived remoteness of mainstream political elites. The politicians whose talk is analysed have different orientations to these antagonistic relationships and use different strategies within their local, socio-cultural and political contexts: Nigel Farage positions himself against the political elite by making claims to the non-mainstream virtues of honesty and frankness; Florian Philippot uses interactional resources in the context of a political debate to undermine his mainstream opponents, while Golden Dawn members engage in linguistic style-shifting (the switch between colloquial and archaic registers) in their criticisms of government policies and the political establishment of the two main parties (PASOK and New Democracy) in Greece.

The different linguistic and discursive features found in the three examples illustrate how style is implicated in situated and socio-culturally significant performances of populist discourse. The extracts have been selected to illustrate various aspects of populist style enacted by a range of right-wing politicians with different political agendas and orientations to populist discourse, rather than because they share specific features or equivalent contexts of broadcast production. By focusing on these three extracts, it is not our intention to provide an exhaustive account of the performative styles through which contemporary populism manifests itself across different socio-cultural contexts; nor do we contend that our data are representative of the stylistic features of populism that exist across countries and continents at large. By contrast, while acknowledging the limitations of our data corpus as comprising only (Western) European examples of political communication, the analysis of these extracts serves to illustrate our qualitative discourse-analytical approach, in which sociolinguistic and cultural variation is a fundamental premise.

\section{Style-shifting as a resource in Golden Dawn's far-right populist discourse}

In this section we examine the discursive resources used by members of the far-right Golden Dawn (GD) party to attribute blame. We show how GD members encode fierce criticisms of 
government policies, the political establishment of the two ruling parties that have dominated politics in Greece since the fall of the military junta (1974) and up until 2015 when left-wing SYRIZA came to power, and mainstream media, by typically resorting to evaluative lexis and tactical switches of register. These switches involve shifting between different available lexical choices in the Greek language, which vary from very formal or archaic to colloquial and slang. These repertoires of talk help bring to life a distinctive performed identity for GD members, and have sociocultural resonance in the context of a crisis-stricken Greece.

There is some debate as to whether GD can be categorised as a populist party due to their neo-nazi background (Stavrakakis and Katsambekis, 2014). Nevertheless, Vasilopoulou and Halikiopoulou, 2015 characterise GD discourse as 'populist ultra-nationalism' that is inextricably related to the financial crisis in Greece (see also Halikiopoulou, 2018; Vasilopoulou et al., 2014). The concept of a populist style as defined by Moffitt, Pels and others in the introductory section would also tend to situate GD as a party articulating a markedly sui generis and socio-culturally specific style of populism. In their public, official performances on mainstream media and the Greek Parliament, GD never allude to neo-nazi ideology or the demise of democracy. On the contrary, as will be shown below, the conflict between 'the people' vs. the vested interests of the political status quo is a constant in their discourse.

First, GD recurrently and typically resort to interactional bad manners and 'name-calling'. In fact, they arguably perform the most disruptive bad manners among the parties represented in the Greek Parliament at present. Consider, for instance, the term

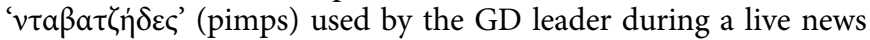
interview on the peripheral KONTRA channel to allude to the mainstream media ${ }^{7}$, that have reportedly excluded GD from live interviews and commentary:

"unfortunately Mr Papagiannis, the pimps of public life, do not respe:ct this".

In Greece, since May 2010 and to this day, the deep recession and spending cuts accompanying the consecutive economic adjustment programmes popularly known as 'Memoranda' imposed by the EU, the European Central Bank (ECB), and the IMF as a condition for securing financial assistance, have put the Greek society under severe strain. At the same time, consecutive elections have brought the far-right Golden Dawn party steadily to the 3rd position in votes (starting with the EU elections of 2014 and consolidated in the following two national elections of 2015).

Blaming (the political establishment, immigration, minority groups, etc.) has been said to lie at the heart of populist communication: "Populism defines who should be blamed for societal issues defined as crisis situations, while absolving the in-group of causal responsibility" (Hameleers, 2017, p. 5). Nonetheless, the literature on populism is characterised by a lack of detailed attention to the nuanced construction of blame in such performances. Here, we explore the lexical choices of GD party members used to assess the (mostly negative) value of political actors and actions other than those of GD.

Register shifts. The sociolinguistic concept of register, or language variation according to use, has been used to designate different scales of formality from formal to informal (Trudgill, 1992), as well as specialised language varieties, such as slang, jargon etc. Register is thus linked to linguistic variation as different language 'styles' are used for different purposes, in different contexts and for different audiences. Functional Grammar offers a more technical definition of register as "a configuration of meanings that are typically associated with a particular situational configuration of field, mode and tenor" (Halliday and Hasan, 1985, p. 38).
As regards GD's lexical choices, blame attribution is achieved through use of bluntly aggressive or derogatory terms. Often, the speakers' critique of the government and casting of dominant politics and policies as unpatriotic, corrupt or immoral is foregrounded through register shifts to colloquial language and slang. However, GD speakers also achieve subtle stylistic and expressive effects by tactically blending elements from different registers (e.g., archaic, formal, colloquial/slang) in the same utterance. To illustrate how this style-shifting functions as a discursive resource in GD talk, we present a selection of extracts from two different mediated performances: a speech addressed to GD supporters (extract 1), and a Parliamentary speech (extract 2).

Extract 1 comes from a commemorative event organised by GD about the 1996 military crisis at the Imia islets, which brought Greece and Turkey to the verge of war:

\section{Extract 1-"The slogan 'scumbags traitors politicians"'}

(F: GD party member; A: audience of GD supporters)

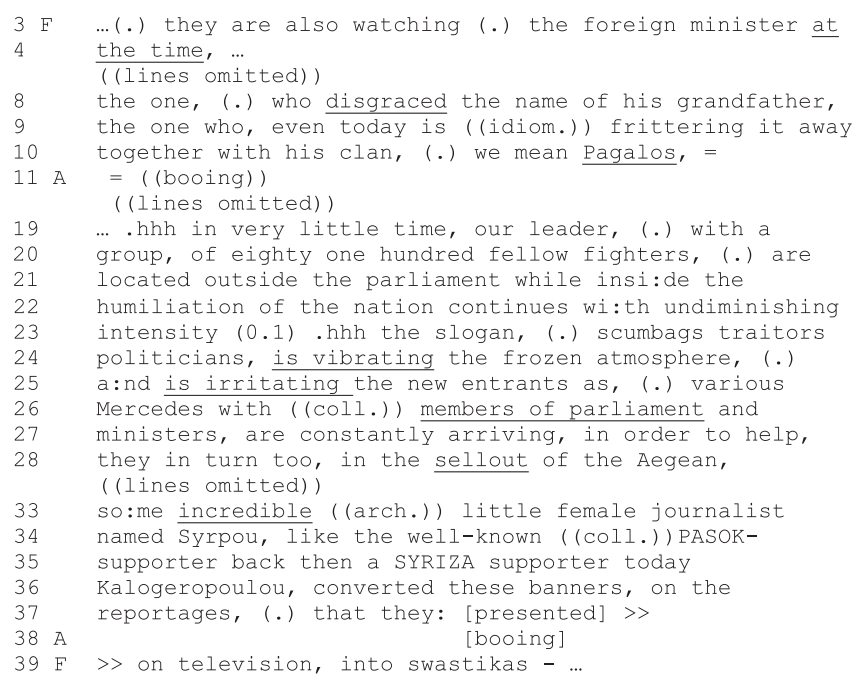

Extract 2 comes from a parliamentary speech .by GD MP K. Barbarousis given on 9 June 2017:

\section{Extract 2 - "You are bringing a memorandum for $\mathbf{5 0}$ years"} (B: Golden Dawn Member of Parliament)

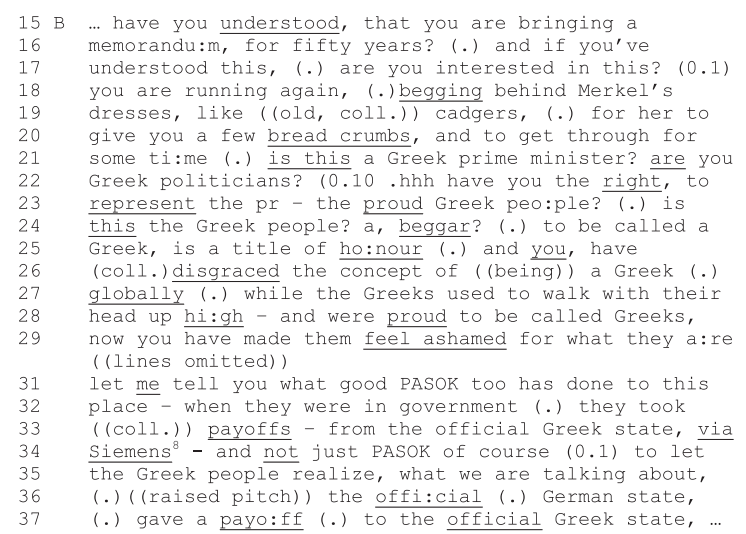

${ }^{8}$ Allusion to the Siemens bribery scandal over alleged deals between Siemens AG and Greek government officials during the 2004 Olympic Games in Athens. Despite the lack of conclusive evidence, the scandal created growing public dissatisfaction with both major political parties in Greece, New Democracy and PASOK.

Overall, in GD discourse, morality blends with common sense/ everyday logic. GD members encode political and social reality in a limited range of items from conversational and colloquial registers, which momentarily shift the style and stand out from the 
surrounding discourse mainly delivered in the standard language. Assessments of value and the notion of blame are semantically built in these items:

In extract 1 , the colloquial item ' $\xi \varepsilon \varphi \tau v \lambda \lambda i \zeta \omega$ ' (to demean, to disgrace) is used to lay blame on the former minister of Foreign Affairs of PASOK, who was in office during the Imia crisis ('the one who disgraced the name of his grandfather', line 8 ). The same verb is used in extract 2 to directly attack the government for having surrendered national sovereignty to Greece's foreign lenders: 'you have disgraced the concept of being a Greek', line 26).

In extract 2 , the vernacular ' $\mu$ ' $\measuredangle \varepsilon c^{\prime}$ ' (payoffs, bribes) symbolically invokes the embezzlement of public funds by corrupt politicians of the status quo; here, the GD speaker alludes to a bribery scandal involving the German multi-national Siemens ('they took payoffs', line 33; 'the official German state gave a payoff to the official Greek state', line 37).

In extracts 1 and 2 , ' $\xi \varepsilon \pi o u ́ \lambda \eta \mu \alpha$ ' (sellout) and ' $\mu \nu \eta \mu o ́ v i o '$ ('memorandum') are two further signifiers denoting - and also connoting - what is constructed as shared socio-cultural knowledge of Greeks as an imagined community ('the sellout of the Aegean', extract 1, line 28). 'Memorandum' refers to the-by now four-financial adjustment programmes imposed since 2010 by Greece's creditors, as in 'have you understood that you are bringing a memorandum for 50 years?', extract 2, lines 15 16). The term epitomises the sacrifices and gradual degradation of Greek people's living standards during the harsh years of the 'memoranda'.

In extract 1 (lines 34-35), another colloquial, derogatory usage designates the female members (or supporters) of the centreleft PASOK party of the political establishment: ' $\pi \alpha \sigma o$ ó $\alpha$ ', while

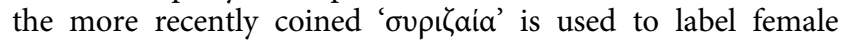
supporters of SYRIZA.

Finally, a similarly culturally resonant term is ' $\delta\llcorner\alpha \pi \lambda o \kappa \eta '$ ' ('entanglement'), as in

"the new entanglement which continues to exi:st"

in the news interview of the GD leader. The term refers to the complex synergies among politics, business and the media (see Iosifidis and Boucas, 2015 about the 'triangle of power' characterising the Greek media landscape).

The lexical items discussed above have a summational force as part of a recognisable public idiom in crisis-stricken Greece, which the audience can understand and identify with. They rest on shared socio-cultural assumptions about political misconduct and corruption, and the impoverishment of the Greek lower and middle classes in the years of the financial austerity programmes (memoranda).

Colloquial, slang and idiomatic words and phrases provide an interpretive framework for the attribution of political responsibility. At the same time, they offer an evaluative framework, i.e., they negatively assess the worth of blamed actors and actions on an ethical scale in an epigrammatic fashion, much like newspaper headlines. Additionally, elements from diverse registers of Greek, i.e., from prototypically archaic/formal and vernacular styles, are brought together as resources for conveying stance and laying blame on members of the political establishment that has "sold out" the country. Relics of the older language situation of diglossia, namely the existence of an archaic, artificial language form (known as 'katharevousa') used in official government documents, in public speaking and education, which was officially resolved in 1976, are present in the discourse of GD; more specifically, in katharevousa and archaic verb endings and the declensional forms of nouns used by GD members.

This is, for instance, the archaic noun ending '-iskos' (meaning

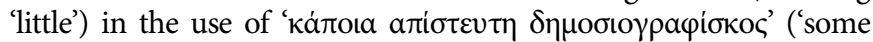

incredible little female journalist', extract 1, line 33) in an attempt to belittle the journalist in question for having reportedly distorted the facts. In the same extract, a similar bizarre co-existence is evidenced in the ancient Greek verb 'Soni' (is vibrating) in the reported chant of the GD members gathered outside the Greek Parliament in 1996 ('the slogan scumbags traitors politicians is vibrating the frozen atmosphere', line 24). Finally, another old-fashioned colloquial

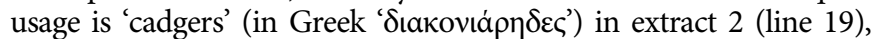
which labels the Greek government's reported pleas for loans to the German chancellor as humiliating acts of beggary.

These elements invest the GD mediated performances with overtones of a learned, official, and now obsolete language form. As the Russian literary theorist and semiotician, Bakhtin, observed about the dialogic quality of language, there is a certain 'heteroglossia' (Bakhtin, 1981) in the performative style of GD. Finally, shifts in style have been linked to the enactment of power in discourse (see Scotton, 1985 about style-shifting as a property of powerful language).

In sum, in these extracts members of the extreme-right party Golden Dawn denounce the media, the government and the two parties of the status quo by resorting to emotionally and socioculturally reverberating lexis and tactical switches to colloquial, or conversely, to archaic, words and expressions in the same utterance. These strategies are part and parcel of the distinct ways of speaking though which GD spokespersons realise their performed public identities. They enact particular value and moral assessments, as they invoke the candour and moral superiority of the ingroup, as they claim an ethical advantage over the corrupt political status quo that has compromised, so the argument goes, the national sovereignty of Greece.

Style-shifting is embedded in an overarching discourse about the Greek crisis and its culprits, for which GD blame the political establishment. In fact, the crisis context and the act of blaming are what sets the GD style of political populism apart from that of Florian Philippot and Nigel Farage, as will be shown in the sections below. This point lends support to the sociocultural resonance of discursive strategies. Furthermore, these sui generis mediated performances distinguish GD from the more technocratic, less disruptive, performances of the mainstream politicians of the past both on the left and right of the centre of the political spectrum in Greece.

\section{Philippot's interactional 'bad manners' in a political debate}

Florian Philippot joined the Front National in $2011^{8}$. He played a key role in distancing Marine Le Pen from the extreme right wing discourse of her father, constructing a more 'acceptable', mainstream public image for the party, and was put in charge of communication strategy in the presidential election campaign of 2017. In the 2014 EU parliamentary elections he stood as a candidate in the 'Grand Est' - a region in eastern France where the FN was ahead in the polls, with a predicted $26 \%$ of the vote.

Unlike some populist politicians, Philippot is not an outsider to the political establishment, but part of the political elite in France, educated at two of the top business (HEC) and administrative (ENA) schools in Paris. The French media has courted him-he was a sought- after participant in debates and interviews in the run-up to both the 2014 European and 2017 presidential elections. Le Figaro (21/09/2017) commented that:

His main accomplishment has been to bring the FN out of its media marginality. A tireless guest in all the TV studios, he has become one of the best known faces of the party, which he assures us is no longer far right.

Philippot's style thus appears to have won him a certain cultural capital within the French media, if ultimately not with his party or FN voters (he did not win a seat during the municipal elections in 2014, and is not a member of the French parliament). 
The data selected here is taken from a TV debate on TF1, the major French commercial channel, where he is on the platform with UMP candidate Nadine Morano and PS candidate Catherine Trautmann. It represents a case of populist performative style as 'bad manners' (Moffitt 2016), and focuses on the interactional resources Philippot uses to consistently undermine the two other candidates during the debate, and overturn some of the conventional rules of the mediated political event. He is seen here, as Pels (2003) suggests, 'fusing message and package', taking up an anti-establishment stance (Krämer, 2014) through his performance in the relational and dynamic context of the debate. The topic being discussed is unemployment and 'social dumping', , but it quickly develops into an argument about political credibility.

\section{Extract 3}

Débat: 'Les Européennes' (LCI/Europe1/Le Figaro). Hosts: Journalists Michel Field and Nicolas Poincaré

Participants: C Trautmann (PS) F Philippot (FN) N Morano (UMP)

Each candidate is allowed the same measured amount of time to speak

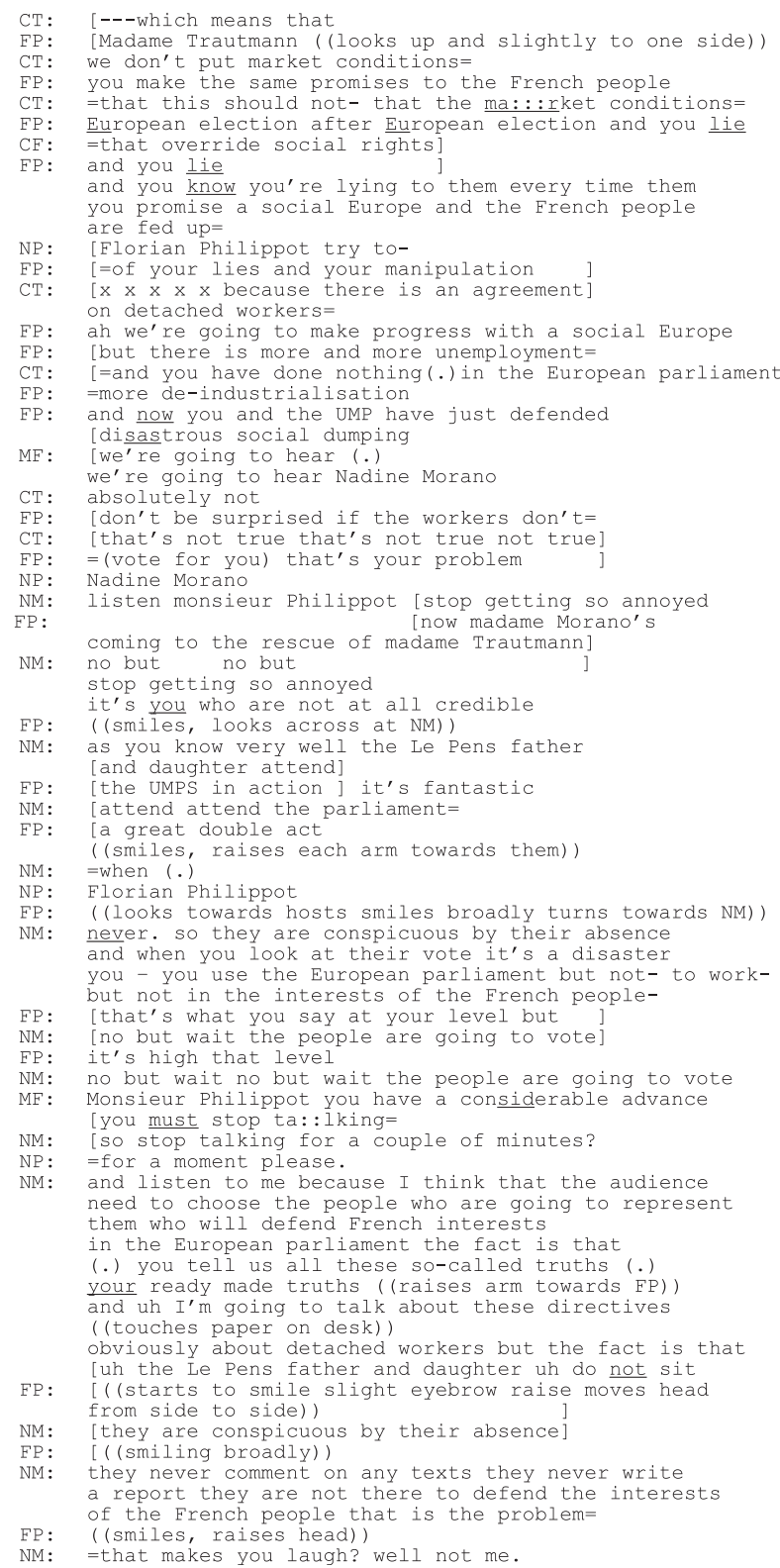

The first thing to note in the extract is the extensive overlapping of participant turns, and that not all the talk is audible. While this is not unusual in French TV debates, which rarely hold to the one-speaker-at-a-time rule, how Philippot interacts with his opponents here constitutes a form of 'incorrect' behaviour (Moffitt 2016). In lines 2-8 he interrupts Trautmann and takes the floor in parallel with her; she repeats and reemphasises her point about 'market conditions', competing with his interruptive turn, but he continues his accusation (the PS is lying to the people) as far as line 27 , closing this long turn with 'that's your problem'. The hosts attempt to re-allocate the floor to Morano in lines 12 and 22, but only succeed in line 28. Field reprimands Philippot again in line 43 , and most explicitly in line 53, 'you must stop talking'. From this point on, Philippot does not interrupt Morano but his non-verbal expression, a broad smile (Fig. 2), clearly communicates his response as direct addressee and recipient of her turn.

The second point, related to the first, is what he accomplishes in these interruptive turns, which from line 30 onwards are not so much bids for the floor as evaluative commentary on the actions of his co-participants. In line 29 Morano tells him to 'listen' but his response (line 28) is addressed to viewers, not directly to her. He refers to her in the third person: 'Mme Morano is coming to the rescue of Mme Trautmann' and continues in lines 38 and 40 to talk about them, not to them. He refers to them as one party: 'the UMPS', raising each arm towards them on either side as he says 'a great double act'. Figure 1 shows his facial expression at line 35 , a smile which broadens (line 44 ) as he turns towards the host, who has just reprimanded him (line 43). In lines 49 and 51, he responds to Morano's criticism of the Le Pens by accusing her of speaking from 'a high level', foregrounding her 'elite' status. Figure 2 shows another very broad smile (line 70) in response to Morano's repeated criticism that neither Jean-Marie nor Marine Le Pen are active members of the European parliament. Philippot seems to be expressing non-verbally a form of amused scepticism in receipt of her talk, and following his prior comment about the UMPS as 'a great double act', the ironic keying of that turn is maintained by his smile. Morano's final turn in the extract, 'that makes you laugh' (line 75), is her response to this non-verbal activity, not to anything he has said.

This sequence illustrates a specific communicative context referred to in the introduction (Charadeau 2013, Herkman, 2016) in which Philippot engages in the consistent undermining of his coparticipants, making fun of them for the viewers in an interactional performance that goes against the normative rules of the mediated speech event. He talks more than the other two politicians, despite the strict time allocation. He refers to the other parties as a single entity, the 'UMPS', the established powerful elite, also a key feature of populist discourse. In his turns he is disruptive, his smile is

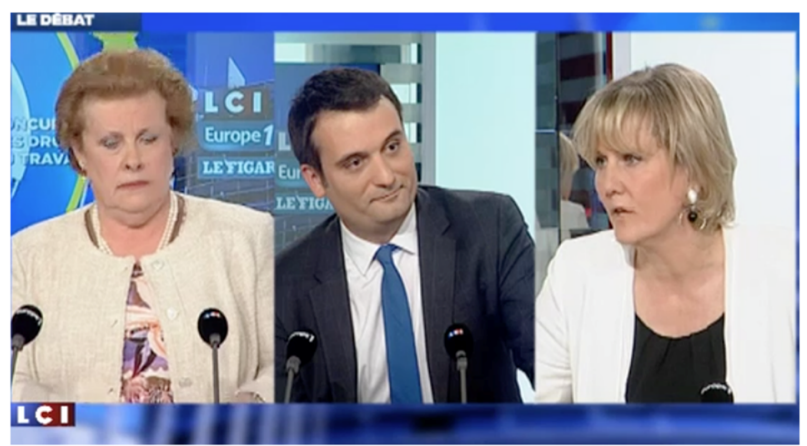

Fig. 1 Florian Phillipot smiles and looks across at Nadine Morano. This figure is not covered by a CC-BY license 


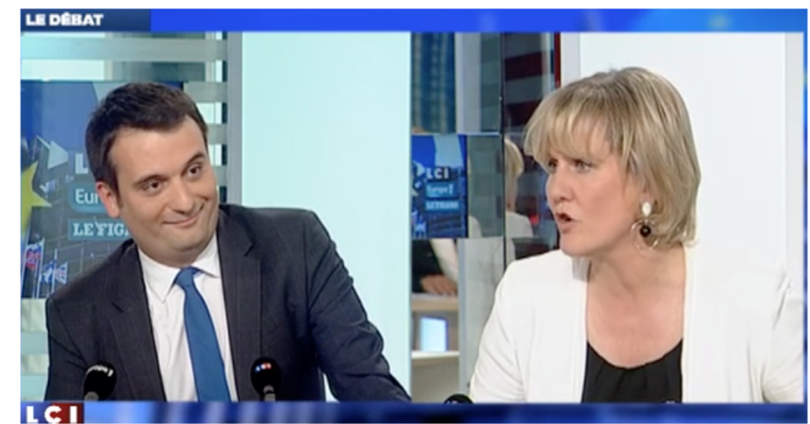

Fig. 2 Florian Philippot smiling broadly, turns towards Morano. This figure is not covered by a CC-BY license

condescending and sceptical compared to the serious demeanour of Trautmann and Morano, and he distances himself from them with this non-verbal behaviour that projects a self-assured appearance of enjoying himself at their expense.

If populism is 'less of a programme than a style of communication' (Lits, 2017) then this example shows how populist style can be analysed here in terms of situated, interactional incorrectness, going against the establishment norms of behaviour in a mediated context for political debate. Philippot's performative style is discursively produced through his manipulation of interactional resources, his 'way of behaving', in which he sets himself against the elite 'double act' of his political opponents.

\section{Farage speaking candidly}

The appeal to the people and the discursive articulations of antagonistic relationships between the people and the power bloc are frequently described characteristics of political populism (Canovan, 1999, Laclau, 2005, Moffitt, 2016). Analyses of political styles suggest that the related claiming of an exclusive representation of the people is performed not only (or even primarily) in politicians taking up peoples' concerns in political promises and programs, but in their ways of acting and being in public settings.

While our analyses in the previous sections have focused on specific linguistic and interactional resources, this section on Nigel Farage illustrates how appearing to be close to the people and distant from the political elite is accomplished when a mix of discursive strategies are enacted in different settings of mediated political communication. Drawing on Pels (2003), our analysis aims to show how the distinctiveness of a populist style, "as a symbolic whole", is shaped and reshaped in an "ensemble of ways of speaking, acting, looking ...” (Pels 2003: 45). Among Farage's frequent media appearances in recent years we have chosen a few moments from interviews, debates and speeches, and focus particularly on how discursive resources are mobilised in the performance of 'speaking frankly'.

Farage on smoking: Candour in an informal backstage setting. In the media, Nigel Farage is often seen smoking his 'fag' (cigarette), sometimes also with a pint of beer in his hand. In recent election campaigns, news broadcasts have reported on Farage in everyday settings, walking around in the street chatting with people and visiting traditional British pubs. The organisation of the campaign activities has enabled him to perform a form of ordinariness and represent a vernacular voice in contrast to the mainstream of political campaigning (Ekström and Morton, 2017). However, Farage has also been involved in discussions on smoking, questioning (and mocking) medical expertise, health organisations and the Government from a typical anti-establishment position (see for example articles in The Daily Telegraph and The Evening Standard
Online 2016). To illustrate how a distinctive populist style is enacted in his talk about smoking, we present an example from a conversation with a journalist in a taxi, broadcast in Dateline (a current affairs program on SBS Australia) ${ }^{10}$. In contrast to most mediated political interviews this conversation is featured as informal talk in a back stage setting.

\section{Extract 4}

(Farage on smoking in an interview in a taxi)

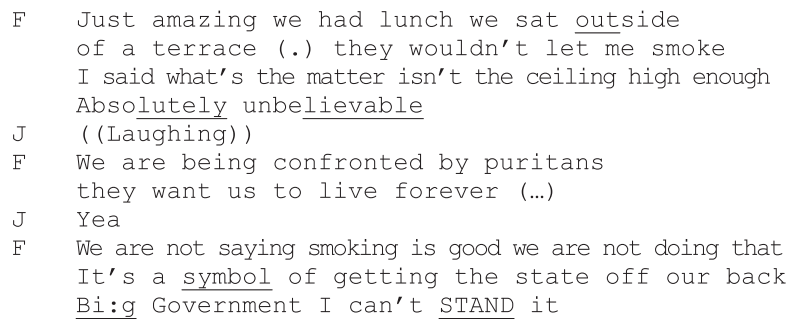

$\mathrm{F}=$ Farage; $\mathrm{J}=$ Journalist

Farage constructs an antagonistic relationship between a 'we' (possible to understand as 'we smokers', as well as 'we, the people') and the Government. He talks bluntly and uses hyperbolic language, articulating strong opinions. The performed frankness marks a clear contrast to the polished and sophisticated talk of political leaders in most public contexts. The journalist affiliates with him in laughter and response tokens. Most importantly, Farage claims a moral high ground in the way he narrates (and represents) authentic experiences from an ordinary situation, and describes the smoking ban as an act of "confrontation" from puritans and "Big Government".

Farage on Brexit: Frankness on the front stage of the political establishment. Farage does not restrict his frankness to informal back stage settings. His blunt and unpolished talk in public debates and formal political institutions has received much attention in the media, for example, his speeches in the EU parliament during the Brexit negotiations. These clearly show how the semiotic potential of a populist style ('the ways of being') is dependent on the particular context in which discursive resources are mobilised. In the extract below, we join the speech when Farage has talked (ironically) about the unreasonable demands that the EU is putting on the UK for Brexit.

\section{Extract 5}

(Farage live on BBC: EU speech in the Parliament in Strasbourg, April 5 2017)

\section{$\mathrm{F}=$ Farage $\mathrm{C}=$ Chair; $\mathrm{CT}=$ Chair translated}

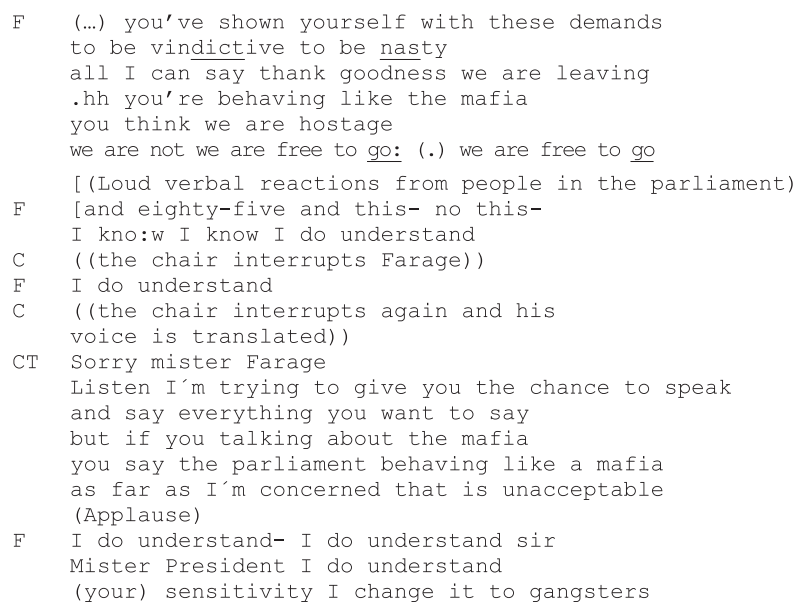


In this context, frankness turns into 'bad manners' (cf. Moffitt, 2016) most clearly when Farage addresses the parliament (you) and describes what they are doing to Britain using a series of negative evaluative attributions (vindictive, nasty, like the mafia). $\mathrm{He}$ obviously challenges the norms of conduct in the EU Parliament, as we see in the reactions from the Members of Parliament (Line 7) and in the chairman's reprimand (Line 14). The reprimand, however, not only helps to display Farage's populist style, but gives him the opportunity to provocatively (and playfully) rephrase 'mafia' into 'gangsters' (Line 23). In the way Farage argues for Britain's independence from the EU, he also demonstrates his independence from the discursive norms of the EU parliament. These norms provide the context for an efficient appropriation of an outsider, and anti-establishment, identity (see Serazio, 2016). In this context, frank and direct talk allows him to claim social capital as he performs being an outsider. Frank talk is thus more than single playful utterances. It is a way of talking (and being) and a discursive strategy that allows him to enact a populist discourse.

\section{"Come on let's be honest"}

The claim of 'saying what people really believe', unlike what elite people normally say in public, is a characteristic of populist styles, and speaking frankly is one way of doing this. Meta-discursively calling attention to 'honesty' as a property of the content of his talk is another. In several examples we see Farage reframing interactions, by offering a more honest talk about politics. Two examples are selected to show how this resource is mobilised in different contexts of interaction. The first one is from the European Parliament Election campaign in May 2014, and one of the news interviews in which Farage was held accountable for a remark (in a radio interview) about peoples' concerns of living next door to "Romanians". He was criticised in the media for giving voice to racist opinions. In the extract below we join the interaction when the political editor, Nick Robinson (after a sequence of arguing about what Farage really said and what he meant), asks a polar question addressing the issue of what is acceptable, and what is not.

\section{Extract 6}

(Accountability interview with Farage, May 192014 BBC)

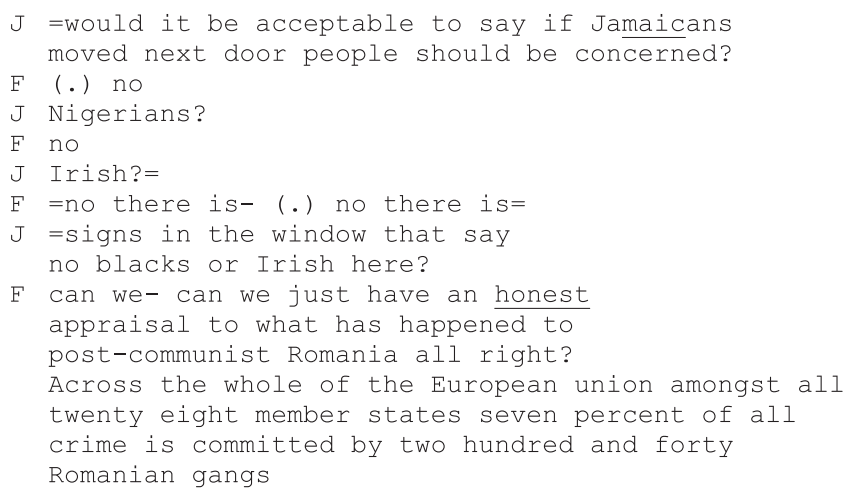

The interview develops into an aggressive repeat questioning (Ekström and Tolson, 2017). The questions are not asked to provide new information about Farage's opinions (they are clearly designed for a preferred 'no' answer), but rather to corner Farage into admitting that he accepts other groups but not Romanians and thus ultimately accuse him of racism. After answering "no" to three questions, Farage changes his strategy to handle the increasingly aggressive and face-threatening situation and produces a frame shift (line 27). He includes the journalist in a "we", shifts the agenda by proposing an "honest appraisal" and draws the attention to factual analysis of crime rates among Romanians. Such reframing (to a more fact-based frame and explicit reference to honesty) is of course not the only way to perform candour. Nor are such references to honesty exclusive to a populist style. It is the context in which the resource is mobilised that matters. It is possible to interpret the frame shift as an evasive response to the question. However, it also questions the legitimacy of the aggressive interviewing, suggesting that there are more sincere and substantive ways of talking about the real problems in society than the strategy used by the journalist. Farage thus claims an authentic voice (cf. Montgomery, 2017).

Our final example is taken from a debate on immigration in Question Time, a BBC current affairs program, broadcast before the European Parliament Elections in 2014. Representatives of different political parties are sitting at the podium, debating and answering questions from journalists and the audience. On line 4 in the extract, Farage again refers to honesty.

\section{Extract 7}

(Debate on immigration and free movement, Question Time BBC 1 May 8, 2014)

$\mathrm{F}=$ Nigel Farage; $\mathrm{U}=$ Chuka Ummuna (MP, Labour); Grant Shapps (MP, the Conservative party)

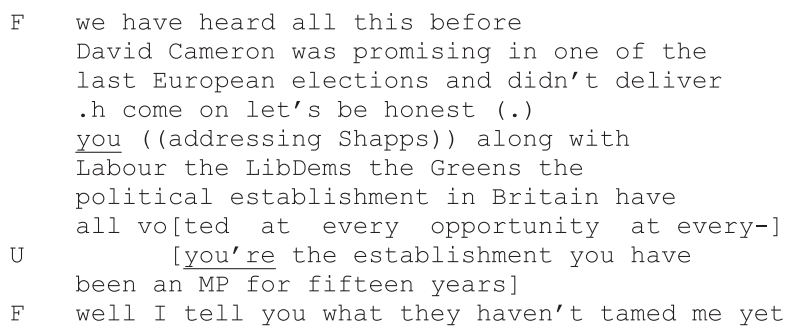

In this example, Farage addresses the MPs at the podium in a more informal style, "come on let's be honest", suggesting that it is time to be sincere and tell it like it is. He (rhetorically) invites the politician to take part in this, 'come on', and at the same time marks his own sincere talk as different from what the other politicians are doing. The strategy is used to criticise the other parties, represented as a collective entity: 'the political establishment'. In contrast to the previous example, the appeal to honesty is thus mobilised in blaming the establishment, rather than in challenging the norms and frames of talk in public discourse. Interestingly, in this debate, Farage is interrupted by one of the MPs, arguing that Farage is actually part of the establishment (Line 9). There is obviously an irony for populist politicians, who have been part of the political and/or financial elite for a long time, claiming to be outside the establishment or appearing to be close to the people (Serazio, 2016, p. 181). Farage is, however, quick to respond, addressing the MP in an informal style saying that they haven't 'tamed him yet'. The social capital claimed by populist politicians in the discursive performance of candour seems to be directly related to this: not only being different from the establishment, but bravely resisting all the the efforts to be tamed by the mainstream political culture.

\section{Conclusions}

In this study we have developed a discourse approach to populism as a performative style, with the aim of contributing to a more rigorous conceptualisation of mediated populism, lacking in most political communication literature on the topic. We have outlined four important aspects of style that need to be considered in the analysis of mediated political performance: 
signifying practices, embodied behaviours, local interactional contexts and hierarchies of moral/cultural 'capital'. In the three case studies, we have shown how different semiotic choices in terms of linguistic register shifting, interactional behaviours, and discursive strategies are mobilised as 'styling resources' by rightwing populist politicians in Greece, France, and Britain. These resources are part and parcel of socio-culturally meaningful performative styles, namely of distinctive repertoires of speaking and behaving, that enable populist politicians to realise their public identities. Through their tactical deployment, populist politicians come forward as candid and authentic-albeit disruptive. Conversely, the discursive 'bad manners' and abrupt style shifting that disrupt expectations of 'appropriate' political communication are precisely at least in part-what invests these discursive performances with overtones of candidness and authenticity. Moreover, populist politicians appeal to 'the people' by claiming the moral high ground, subverting and undermining the establishment, and producing identity performances that signify closeness to 'the people', as opposed to the perceived remoteness of mainstream political elites. Thus, they claim social and cultural capital in their respective contexts of communication.

There is no one single or exclusive populist 'style'; rather, populist styles are produced in distinct socio-cultural contexts of which we have offered some illustrative examples. Of course, there is an array of other resources that can become contextually relevant in the production of a style that is disruptive of communicative norms in specific politically mediated settings. It becomes clear, therefore, that, rather than concentrating on solely ideological distinctions, to gain a deeper insight into populism we need to understand politics as a dynamic process of producing socio-cultural meanings in concrete contexts of communication by means of mobilising a range of semiotic resources.

The arguments presented here should not be interpreted as claims that populism is nothing but style-form in a vacuum of content. Rather, acknowledging the ideological basis of populism as discourses that are predicated on the construction of an antagonistic relationship between the people and the elite, we stress the need for rigorous inter-disciplinary analysis in which close attention to style as culturally meaningful deployment of discursive and semiotic resources plays a crucial role. In this effort, the theoretical perspectives and analytical tools provided by sociolinguistic discourse analysis can further our understanding of the dynamics and situated enactment of contemporary mediated political populism. Although the research on populist styles is on the rise (Bossetta, 2017; Moffitt, 2016), a fruitful avenue of investigation that still remains largely unexplored is how discursive and semiotic 'styling resources' are mobilised in populist performances, in different communicative and socio-cultural contexts, and in the service of particular political agendas and ideologies.

Received: 11 December 2017 Accepted: 1 May 2018

Published online: 03 July 2018

\section{Notes}

1 F2 L'Entretien decisif 04052017

2 BBC Radio 4 The World Tonight 15062017

3 See particularly the recent special issue of the Journal of Language and Politics 2017.

4 The Welsh Labour politician and health minister largely responsible for the creation of the British National Health Service in 1945

5 This claim was frequently used in vox pop interviews with UKIP supporters in the 2014 EU parliamentary elections.

6 This corpus consists of TV data collected over a period of three weeks covering the EU parliamentary elections in 2014 (Ekström and Firmstone 2017) and a more recent corpus of TV and press data collected in France, Greece, Sweden and the UK covering significant political events in 2016-2017.

7 Mainstream television channels have imposed an embargo on GD by excluding them from live interviews and talk show panels, following a 2012 incident, where the GD spokesperson, Ilias Kasidiaris, slapped a female politician of the Greek communist party and threw water over another live on a daily morning political show.

8 Philippot has recently quit his role as VP of the FN (not accepted by others within the party because of his influence over MLP who blamed him for her defeat in the recent presidential elections) and founded his own party, 'Les Patriotes'.

9 'A recurring term in discussions related to working mobility, wages and the social security of workers, social dumping has neither a generally accepted definition, nor easily definable limits.' (Europa 'ThinkTank'definition 2017)

10 The clip is available on https://www.youtube.com/watch?v $=$ gP8HrLhA9hc

\section{References}

Bakhtin M (1981) The dialogic imagination: four essays. In: Holquist M (ed) (trans: Holquist M, Emerson C). University of Texas Press, Emerson, Austin

Bell A (1991) The language of news media. Blackwell, Oxford

Bossetta M (2017) Fighting fire with fire: mainstream adoption of the populist political style in the 2014 Europe debates between Nick Clegg and Nigel Farage. Br J Polit Int Relat 19(4):715-734

Bourdieu P (1991) Language and symbolic power. Polity Press, Cambridge

Canovan M (1999) Trust the people! Populism and the two faces of democracy. Polit Stud 47:2-16

Charadeau P (2013) Réflexions pour l'analyse du discours populiste. Mots. Les langages du politique. http://mots.revues.org/20534. Accessed 8 Nov 2017

Corner J, Pels D (eds) (2003) Media and the restyling of politics: consumerism, celebrity and cynicism. Sage, London

Coupland N (2007) Style: Language Variation and Identity. Cambridge University Press, Cambridge, http://www.telegraph.co.uk/business/2016/06/16/its-easyto-mock-experts-and-the-establishment-but-stable-govern/ Daily Telegraph Online

De Cleen B, Stavrakakis Y (2017) Distinctions and articulations: a discourse theoretical framework for the study of populism and nationalism. Javnost-The Public. https://doi.org/10.1080/13183233.2017.1330083

Ekström M, Morton A (2017) The performances of right-wing populism: Populist discourse, embodied styles and forms of news reporting. In: Ekström M, Firmstone J (eds) The Mediated Politics of Europe: a comparative study of discourse. Palgrave Macmillan, Cham, Switzerland, pp 289-318

Ekström M, Tolson A (2017) Citizens talking politics in the news: Opinions, attitudes and (dis)engagement. In: Ekström M, Firmstone J (eds) The Mediated Politics of Europe: A Comparative Study of Discourse. Palgrave Macmillan, Cham, Switzerland, pp 201-228

Europa Think Tank (2017) http://www.europarl.europa.eu/thinktank/en/ document.html?reference=EPRS_BRI(2017)599353. Accessed 12 Dec 2017

Evening Standard Online (2016) https://www.standard.co.uk/news/uk/nigel-faragemocked-for-blasting-world-health-experts-as-bullies-over-smoking-warninga3688431.html Accessed 12 Dec 2017

Fairclough N (2000) New Labour, New Language? Routledge, London

Fairclough N (2016) A dialectic-relational approach to critical discourse analysis in social research. In: Wodak R, Meyer M (eds) Methods of critical discourse studies. Sage, London, p 86-108

Goffman E (1959) The Presentation of Self in Everyday Life. Doubleday, Garden City, NJ

Halliday MAK, Hasan R (1985) Language, context and text: aspects of language in a social-semiotic perspective. Oxford University Press, Oxford

Halikiopoulou D (2018) The Far Right Challenge; Comment on The Rise of Posttruth Populism in Pluralist Liberal Democracies: challenges for Health Policy. Int J Health Policy Manag 7(2):195-198

Hameleers M (2017) A typology of populism: towards a new theoretical framework on the sender-side and receiver-side of communication. Paper presented at International Communication Conference (ICA).

Herkman J (2016) Articulations of populism: the nordic case. Cultural Stud https:// doi.org/10.1080/09502386.2016.1232421

Higgins M (2013) Governmentality, populism and empowerment: David Cameron's rhetoric of the big society, in Richard Scullion. In: Roman Gerodimos Dan, Jackson, Lilleker Darren (eds) The Media, Political Participation and Empowerment. Routledge, Abingdon, p 58-70

Iosifidis P and Boucas D (2015) Media Policy and Independent Journalism in Greece. Open Soc Foundation. www.opensocietyfoundations.org/sites/ default/files/media-policy-independent-journalism-greece-20150511.pdf

Krämer B (2014) Media populism: a conceptual clarification and some theses on its effects. Commun Theory 24(1):42-60

Kress G (2010) Multimodality: a social semiotic approach to contemporary communication. Routledge, London

Laclau E (2005) On populist reason. Verso, London

Lits M (2017) On Mashable, France 24: http://mashable.france24. com/monde/ 20170129-populisme-demagogie-difference-politique Accessed 12 Dec 2017 
Moffitt B (2016) The global rise of populism: performance, political style, and representation. Stanford University Press, Stanford

Montgomery M (1999) Speaking sincerely: public reactions to the death of Diana. Lang Lit 8(1):5-33

Montgomery M (2017) Post-truth politics? Authenticity, populism and the electoral discourses of Donald Trump. J Lang Polit 16(4):619-639

Mortensen J, Coupland N, Thøgerson J (eds) (2017) Style, mediation and change: sociolinguistic perspectives on talking media. OUP, Oxford

Mudde C (2007) Populist radical right parties in Europe. Cambridge University Press, Cambridge

Muller J (2016) What is populism? University of Pennsylvania Press, Pennsylvania

Myers G (2000) Entitlement and sincerity in broadcast interviews about Princess Diana. Media Cult \& Soc 22(2):167-185

Pels D (2003) Aesthetic representation and political style: Re-balancing identity and difference in media democracy. In: Corner J, Pels D (eds) Media and the Restyling of Politics: Consumerism, elebrity andCynicism Celebrity and Cynicism. London, Sage, pp 41-66

Sacks H (1984) On doing 'being ordinary. In: Atkinson JM, Heritage J(eds) Structures of social action: studies in conversation analysis. CUP, Cambridge, pp 413-429

Serazio M (2016) Encoding the paranoid style in American politics: antiestablishment discourse and power in contemporary spin. Crit Stud Media Commun 33:181-194

Schoor C (2017) In the theater of political style: touches of populism, pluralism and elitism in speeches of politicians. Discourse \& Soc 28(6):657-676

Scotton CM (1985) What the Heck, Sir: style shifting and lexical colouring as features of powerful language. In: Street RL, Cappella JN (eds) Sequence and pattern in communicative behaviour. Edward Arnold, London, pp 103-119

Stavrakakis Y, Katsambekis G (2014) Left-wing populism in the European periphery: the case of SYRIZA. J Political Ideol 19(2):119-142

Street J (2003) The celebrity politician. Political style and popular culture. In: Corner J, Pels JD (eds) Media and the restyling of politics: consumerism, celebrity and cynicism. Sage, London, pp 85-98. (2003)

Thornborrow J (2015) The discourse of public participation media: from talk show to Twitter. Routledge, London

Thornborrow J (2015) Style, key and the new poetics of television news. 'Traversées/Crossings’ Etudes De Stylist Angl 3:121-140. 7, Édition Universitée Lyon

Thornborrow J, Van Leeuwen T (eds) (2001) Authenticity in Media Discourse, Special issue of Discourse Studies, 3(4).

Tolson A (2006) Media talk: spoken discourse on TV and Radio. Edinburgh University Press, Edinburgh

Trudgill P (1992) Introducing language and society. Penguin, London
Van Leeuwen T (2008) Discourse and practice. Oxford University Press, Oxford Vasilopoulou S, Halikiopoulou D, Exadaktylos T (2014) Greece in crisis: austerity, populism and the politics of blame. J Common Mark Stud 2014(52):388-402

Vasilopoulou S, Halikiopoulou D (2015) The Myth of National Rebirth: The Golden Dawn's Populist Ultra-nationalism. The Golden Dawn's 'Nationalist Solution': Explaining the Rise of the Far Right in Greece. Palgrave Macmillan, New York, p 64-77. Reform and Transition in the Mediterranean

\section{Acknowledgements}

The authors would like to thank the Swedish Research Council for their funding of the project "Right-wing populism in the news media: a cross-cultural study of journalist practices and news discourse", colleagues at the Ross Priory International Seminar on Broadcast Talk 2017 for their comments on an early version of this paper, which has helped shape what it is today.

\section{Additional information}

Competing interests: The authors declare no competing interests.

Reprints and permission information is available online at http://www.nature.com/ reprints

Publisher's note Springer Nature remains neutral with regard to jurisdictional claims in published maps and institutional affiliations.

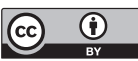

Open Access This article is licensed under a Creative Commons Attribution 4.0 International License, which permits use, sharing, adaptation, distribution and reproduction in any medium or format, as long as you give appropriate credit to the original author(s) and the source, provide a link to the Creative Commons license, and indicate if changes were made. The images or other third party material in this article are included in the article's Creative Commons license, unles indicated otherwise in a credit line to the material. If material is not included in the article's Creative Commons license and your intended use is not permitted by statutory regulation or exceeds the permitted use, you will need to obtain permission directly from the copyright holder. To view a copy of this license, visit http://creativecommons.org/ licenses/by/4.0/.

(c) The Author(s) 2018 